\title{
ORGANIZATIONAL AND LEGAL REGULATION OF THE FINANCIAL SECTOR OF THE ECONOMY AMID EUROPEAN INTEGRATION
}

\author{
Oleksii Fedotov', Svetlana Levchenko²
}

\begin{abstract}
Financial sector development depends on the efficiency of its regulatory mechanisms that should correspond to the directions of implementation of state financial policy, which is aimed at the support for economic stability, protection of interests of participants in financial markets, and provision of rational use of growing financial market potential. Introduction of the mechanism of organisational and legal regulation is able to implement a complex approach to the application of various methods, means, other regulators on processes of effective formation and use of state financial resources in order to ensure their coordination and correspondence to strategic development priorities of the state. The purpose of the article is to substantiate features of organisational and legal regulation of the financial sector of the economy of EU countries and Ukraine, identify the main directions for reformation and recommendations for its improvement in the context of European integration trends and the possibility of securing competitive positions of Ukraine in the international market. The most widespread in the world are two models for regulating the financial sector's activity - sectoral model and mega-regulator model. In the sectoral model, functions of public authorities are distributed according to three financial sectors (banking, insurance, stock). The model of mega-regulator determines the peculiarities of establishing a single authority endowed with functions of supervision and regulation of the financial sector. At the modern state of countries' development, the main methods and forms of state regulation of the financial sector are determined by direct (development and adoption of laws and regulations, licensing of the activities, supervisory activities and implementation of measures of supervision of financial institutions) and indirect (changes in the volume of cash resources, securities issue, interest policy, provision of guarantees on fulfilment of obligations for securities of separate issuers, encouragement of foreign relations with international financial organisations) influence. Financial sector regulation in the EU and Ukraine is carried out according to the sectoral model where banking activities are subject to the Central Bank; activities in the market for securities are regulated by the National Securities and Stock Market Commission; activities of other financial intermediaries and financial companies are regulated by the National Commission for State Regulation of Financial Services Markets. Results of the research conducted allow determining the features of state regulation of the financial sector of the economy of Ukraine: the lack of legislative environment for regulating the financial status at the macrolevel and microlevel; provisions of the existing regulatory framework are aimed at the regulation of economic security; the absence of strategic benchmarks fixed in long-term documents for ensuring financial development of the country and the economic development of financial institutions; the presence of several regulators of the state of the financial system that duplicates functions and causes inefficient work; information closeness of regulators of financial market and financial system regarding the results of their work on ensuring the financial stability of the state. In order to improve rating positions and competitive advantages of Ukraine in global markets, it is necessary to develop additive legal framework and state support program for export-oriented enterprises for the promotion of export of finished products with high added value; start the policy of expansion on the basis of expansion of both geographical and commodity structure of exports.
\end{abstract}

Key words: financial sector, state regulation, state supervision, legal framework, financial institutions, competitiveness, European integration.

JEL Classification: E44, E62, F36, K33

\footnotetext{
Corresponding author:

${ }^{1}$ National University “Odessa Law Academy”

E-mail: fedotov_ap@ukr.net

${ }^{2}$ E-mail: lightstarpro@ukr.net
} 


\section{Introduction}

In terms of dynamic changes in the world economy under the influence of crisis phenomena, the need arises to improve the activity of the financial sector that is one of the basic elements of the existence of each state. Stable functioning of the financial sector is one of the factors stimulating the country's dynamic development. Financial sector development depends on the efficiency of its regulatory mechanisms that should correspond to the directions of implementation of state financial policy, which is aimed at the support for economic stability, protection of interests of participants in financial markets, and provision of rational use of growing financial market potential.

In modern times, the development of the financial sector of the state depends on its institutional structure, and how clearly the tasks of organizational and legal regulation are defined. Therefore, improving the mechanism of organizational and legal regulation of the financial sector should be system and based on the sustainable methodological basis of the institutional approach. Introduction of the mechanism of organisational and legal regulation is able to implement a complex approach to the application of various methods, means, other regulators on processes of effective formation and use of state financial resources in order to ensure their coordination and correspondence to strategic development priorities of the state.

One of the key strategic priorities of the state is to establish parity boundaries of competitiveness in the European market. Given the fact that competitiveness of the economy is a multifaceted, complex, and systemic concept, it is common ground among scholars to distinguish two basic approaches to its interpretation. In the first case, competitiveness is understood as an ability of the state economic system in a free competitive environment to satisfy internal and external market needs and ensure long-term economic growth. Within the second definition, competitive advantages of the national economy are manifested exclusively in international markets and to some extent provide the country's leadership (Skrypnyk, Khyryuddinov, 2016).

The purpose of the article is to substantiate features of the organisational and legal regulation of the financial sector of the economy of EU countries and Ukraine, identify the main directions for reformation and recommendations for its improvement in the context of European integration trends and the possibility of securing competitive positions of Ukraine in the international market.

Financial market development depends on the efficiency of relations in the system "state - financial market participants". The realisation of such relations on the part of the state should be carried out through the organisational-institutional mechanism that is based on a combination of market laws and administrative foundations of state regulation in order to achieve a certain goal.

\section{The methodology of research}

At the modern state of functioning of the economy of Ukraine, development of the financial sector is determined by the perfection of its regulatory system. Because, taking into account regulatory mechanisms of the state financial sector, regulators are created that should coordinate actions regarding the regulation and control of the activities of financial sector entities and the availability and compliance with international norms of other infrastructural elements (Rekunenko, 2013).

The experience of European countries in ensuring, in particular, public administration in the area of the formation of the EU stock market, is a particularly important factor in the progressive movement of the economy of any state. A conscious and consistent approximation to the EU legal acts regulating activities in the sphere of the formation of the EU stock market is a prerequisite for the countries on the way toward the European Union.

A large number of scientists considering issues of financial, legal, and regulatory control of the state focused their research on different directions. Let us outline the main recent vectors of the scientific opinion regarding the consideration of the problems of regulation of the financial sector of the economy.

A number of studies of the following authors are devoted to the analysis of mechanisms for the creation and development of the stock market, the principles of its functioning and organization. M. Barnier, European Commissioner for Internal Trade (The new European, 2017), R. Healey, W. Rhode, M. Mizen studied the issue of derivative regulatory instruments in European markets (Deriv Alert, 2015); Oslund A. considered the cause and consequences of financial market crises that arose in the USA; Eteris Y. U. considered the economiclegal patterns of development and functioning of the financial market in the Baltic States (Eteris, 2018).

However, the dynamics of changes in the world and Ukrainian economic, political, and legal space are so fast and multifaceted that it requires constant refinement, new research and new recommendations regarding the development and implementation of organizational and legal mechanisms for regulating the financial sector of the economy in the context of European integration.

Two models for regulating the financial sector's activity remain the most widespread - sectoral model and mega-regulator model.

In the sectoral model, functions of public authorities are distributed according to three financial sectors (banking, insurance, stock). Mega-regulator model determines the peculiarities of establishing a single authority endowed with functions of supervision and regulation of the financial sector.

The most perfect model is the British mega-regulator model, which combines the functions of supervision and control over investment, banking, mortgage, and 
insurance services. In France, banking supervision and supervision over non-bank financial institutions are divided between the Bank of France and a specially created regulatory body. In Germany, the regulatory model is similar to French, but there are banks in the regulatory area (Bondarenko, 2018).

At the modern stage, in the EU countries and most economically developed countries (Canada, Japan, Great Britain, France) and Ukraine, the main methods and forms of state regulation of the financial sector are determined by direct (development and adoption of laws and regulations, licensing of the activities, supervisory activities, and implementation of measures of supervision of financial institutions) and indirect (changes in the volume of cash resources, securities issue, interest policy, provision of guarantees on fulfilment of obligations for securities of separate issuers, encouragement of foreign relations with international financial organisations) influence.

Financial sector regulation is carried out according to the sectoral model where banking activities are subject to the Central Bank; activities in the market for securities are regulated by the National Securities and Stock Market Commission; activities of other financial intermediaries and financial companies are regulated by the National Commission for State Regulation of Financial Services Markets.

The global financial crisis has proved the need to revise the peculiarities of the functioning of financial sector regulators since it has revealed their weakness in preventing crises in financial markets. Meanwhile, the institutional features of the evolution and formation of the financial market determine the need for further study of the functions and role of organizational and legal regulation of the financial sector and the development of effective mechanisms for its implementation in the context of European integration tendencies.

For studying the public administration system in the field of the formation of the stock market of the EU countries, there is a well-developed source base. It is a systematic array of relevant legislation of the European Union. First of all - the Treaty establishing the European Community (1957) and the Treaty on European Union (Maastricht, February 7, 1992), the next are - Regulation (EU) No. 1095/2010 of the European Parliament and of the Council of 24 November 2010 establishing a European Supervisory Authority (Regulation (EU), 2010), Directive 2004/39/EC of the European Parliament and of the Council of 21 April 2004 on markets in financial instruments amending Council Directives 85/611/EEC and 93/6/EEC (Directive 2004/39/EC), European Parliament resolution of 9 October 2008 with recommendations to the Commission on Lamfalussy follow-up: future structure of supervision (2008/2148(INI)) (Directive 2004/39/EC) and so on.

Mechanisms of organizational and legal regulation of the financial sector should concern not only the rational formation, distribution, and use of financial resources between its elements but also serve as a means of formation of the institutional and legal environment, which will promote consistent changes in the legislative framework, improvement of the legal framework, development of financial institutions. In Ukraine, the period of the reform of institutional support and the formation of new effective mechanisms of functioning of the economy is ongoing. The existing organizational, legal, and economic institutions of market orientation are being developed and new ones are being created.

The application of the institutional approach to regulating the financial sector of the economy makes it possible to comprehensively consider the possibility of its functioning, and organizational and institutional regulation can strengthen the ability of participants to fruitful interaction.

The most important institutes forming the external institutional environment of the financial sector of the economy are (Bondarenko, 2018):

- institute of law regulating legal relations in sectors of the financial market;

- the market institute that regulates the interactions that occur between participants in the process of buying and selling financial assets;

- institute of taxes, which determines the economiclegal relationship between financial institutions and the state;

- institute of public choice that regulates the process of making macroeconomic decisions in conditions of representative democracy;

- institute of education, which forms the appropriate skill level of specialists for the modern financial market; - institute of foreign economic relations, which regulates the financial and legal processes of interaction of domestic institutions with the world financial system.

The development and implementation of a comprehensive system of regulation of the financial sector of the economy, the use of micro-and macroprudential supervision as the sole mechanism for influencing the activities of financial institutions are designed to solve the problems of the financial system of the country (Melykh, 2013).

In the report "De Lazorier's Report", presented on February 25, 2009, the High Level Group (the group of highly qualified experts convened by the President of the European Commission J. Barroso in 2008) recommended strengthening the principles of financial system supervision in order to reduce the risks and burdens of future financial crises. In particular, it was recommended to reform the structure of supervision of the financial sector in the EU. The level of its development required a significant convergence between member states to develop common technical standards for market participants, as well as to establish a mechanism for coordinating national coordinators. The latter would 
make it possible to quickly apply the rules made by regulators at the national financial levels of all EU member states and significantly reduce the period of review in the European Court, ensuring prompt response to adverse events in the market. The High Level Group has come to the conclusion that the European financial supervision system should be set up in three European supervisory bodies, one for each sector: banking, securities, insurance and professional sector of pensions.

The creation of the European Systemic Risk Board was also recommended. Experts insisted that these reforms and actions are urgently needed. Consequently, in the context of the global financial and economic crisis, the European Union finally abandoned the liberalization of the free financial market in favour of strict control by regulators at both the state and pan-European level. Since it is not possible to predict the end of the crisis, EU finance ministers considered it useful to follow the example of the USA: they allowed their banks to reclassify assets in order to create equal conditions for European and American financial institutions. Accordingly, at this time, the legal influence of Europe on the part of the system of governing bodies was changed: there was a gradual transition from the dispositive method of legal regulation of this sphere of social relations to the imperative method.

Based on the report of the expert group, the European Commission made proposals on creating a new system of control and supervision of the financial market in Europe. In September 2010, the European Parliament voted in favour of its implementation and created four new supranational regulators, which came into operation on January 1, 2011, - the European Securities and Markets Authority, the European Insurance and Occupational Pensions Authority, the European Banking Authority; an advisory and analytical body was also created - the European Systemic Risk Board. Therefore, these four authorities constitute today the European System of Financial Supervision. Based on members of these regulators, the Joint Committee is formed, which should meet at least every two months and produce a coordinated program of action and a common position on the regulation of the activities of financial conglomerates.

For the harmonious integration of Ukraine in the EU in the economic and legal framework, it is necessary to perform a number of commitments already declared by the country's leadership. A list of EU Directives to be implemented in Ukraine over a period of 5 years relates to the development of banking, insurance, securities market, co-investment, market infrastructure, antimoney laundering measures, providing free movement of funds and capitals.

So, from the whole list of regulatory acts in the banking sector that Ukraine needs to implement in the coming years, one of the main documents is Directive 2006/48/EC of the European Parliament and of the Council of 14 June 2006 relating to the taking up and the pursuit of the business of credit institutions. In the insurance sphere, it is needed to implement Directive 2009/138/EC of the European Parliament and of the Council of 25 November 2009 on the taking-up and pursuit of the business of Insurance and Reinsurance.

In the financial market - to implement Directive 2004/39/EC of the European Parliament and of the Council of 21 April 2004 on markets in financial instruments, and in the market for joint investment Directive 2009/65/EC of the European Parliament and of the Council of 13 July 2009 on the coordination of laws, regulations and administrative provisions relating to undertakings for collective investment in transferable securities (Verkhovna Rada, 2011).

Based on these provisions, the Comprehensive Program of Ukrainian Financial Sector Development Until 2020 was adopted on 18.06.2015. It includes in the regulatory work plan with a list of activities planned to be implemented, a plan of action for achieving such goals, the time frame, and those responsible for implementing these provisions. In order to achieve its goal and objectives, it provides for implementing the cooperation program with such institutions as the EU, IMF, World Bank, EBRD, EIB, BIS, IOSCO, IAIS, and other international financial organisations, associations, and regulators in the sphere of financial markets and services.

\section{Results and discussion}

Expected from 01.09.2017, the entry into force of the Association Agreement between Ukraine and the EU stipulates the necessity of finding and agreeing with partners the next steps of Ukraine on the way toward its further integration in the European Union structures. It is not known at this time what form will get further integration (customs union, common market, full integration with the subsequent acquisition of membership or some combination of these options), however, this movement will obviously continue, which actualises the issue of analysis of potential risks occurring on the further way of Ukraine toward the structures of the European Union.

Thus, further deepening of the integration of Ukraine and the $\mathrm{EU}$, besides unconditional advantages and additional opportunities in the economic and financial fields, has a set of specific risks that can appear in middle-term perspective. These risks, in particular, are as follows.

At the end of 2013, at the level of the European Union, a Banking Union was established, which united 130 largest Eurozone banks out of 6 thousand Eurozone banks and 8 thousand EU banks under the unified supervision system and provides for three 
basic principles of functioning (Sharov O.M, 2016): the single banking supervisory system controlled by the ECB; the single mechanism for regulating bank failures with a special new fund for the reimbursement of customer losses; the general system of insurance of private bank deposits at the level of up to 100 thousand euros.

Herewith, the rest of the smaller banks remain under control of national regulators. The banking system of Ukraine pales in comparison to banking systems of EU countries because it is actually at the Basel I level while European countries have long since moved to the Basel III level.

For example, the current legislation in Ukraine substantially restricts the movement of capital both for residents and non-residents. In particular, natural and legal persons-residents of Ukraine cannot freely open accounts abroad, send significant sums of currency outside Ukraine without "valid" reasons (treatment, education, etc.). For investment abroad, residents should obtain special licenses of the NBU.

In order to withdraw capital abroad, unscrupulous resident legal entities use a variety of "schemes", the most common of which are fictitious exports and imports. In the first case, the enterprise deliberately sends a certain product abroad, having agreed in advance with the counterparty not to receive payment in Ukraine, which "settled" on the accounts of the enterprise or its actual owners abroad. In the second case, the enterprise makes advance payment for a certain product abroad, in advance agreeing with the business partner that the goods, in fact, will not arrive in Ukraine. In the framework of combating the outflow of capital abroad in this way, the NBU requires from all banks the monthly statistical reporting in the form No. 531 "Report on residents - subjects of foreign economic activity, who exceeded the time limits set by the legislation for payments for export operations" that includes comprehensive information on the legal entity (exporter or importer) in order to further impose penal sanctions thereto.

It is obvious that further deepening of EU-Ukraine integration encourages Ukraine to gradually abandon the strict control of capital movements and the substantial liberalization of currency legislation, as the EU did; however, we believe that it can provoke a significant outflow of capital in the short term. In its turn, it can negatively influence the currency rate dynamics by growing demand in the interbank currency market on the part of foreign investors who will wish to "exit" from Ukraine.

Studying the formation and development of financial and political system of various countries allowed drawing conclusions that ensuring the self-sufficiency of the national economy and strengthening the level of competitiveness of the national economy and the proper positioning of Ukraine in the coordinates of the world financial and economic space should be based on the principles of strict protectionism and implementation of the policy of "import substitution", expansion of production of domestic goods and services, limitation of the supply of imported goods by the public administration sector. Thus, at the expense of protectionist measures, it is possible to restore "stagnant" productions, which in turn will lead to an increase in the number of jobs with an appropriate level of remuneration (Timoshenko, 2016). This measure will have a positive effect on the cessation of the mass emigration of highly skilled labour to the European Union member states, which is determined by the adoption of a visa-free regime. Using protectionist measures, namely administrative levers, it is possible to ensure the social security of low-income sections of the population, free education, medicine, etc.

The author fully understands that on a world scale, in the long run, levers and measures of protectionist policy can lead to the historical collapse of the national economy; nevertheless, in the new economic reality in Ukraine, these measures are important and argued (irrational import structure, "import substitution" policy of the Russian Federation, military-political conflict of Ukraine, loss of the mainland territory of Ukraine, ineffective quota system for agricultural products set by the European Community, etc.). Moreover, it cannot be ignored that today the overwhelming majority of countries in the world are also defending the position of protectionism.

The influence of globalisation on the economy and financial sector of Ukraine can be traced through intergovernmental comparisons and dynamics of the country's place in world economic ratings. So, the index of globalization is indicative, which is based on the assessment of the level of international relations of the country, its integration and independence by 24 indicators broken down into three categories: economic, social, and political globalization. Ukraine ranks 47 th out of 207 countries with a score of $67.78 \%$, in particular, 64th place by the economic component (64.84 points), 69th - by the social component (57.78 points), $42 \mathrm{nd}$ - by the political component ( 86.07 points). The situation has somewhat changed over the previous three years when the country has been steadily at the 44th place (The position of Ukraine in the world ranking according to the Global Competitiveness Index 2016-2017).

Another important rating of the country's place in universal space is the Global Competitiveness Index that is calculated by the methodology of the World Economic Forum since 2004 based on 113 indicators combined in 12 groups (The position of Ukraine in the world ranking according to the Global Competitiveness Index 2016-2017). One of the most essential institutional constraints on the accelerated economic development of Ukraine, in particular, 


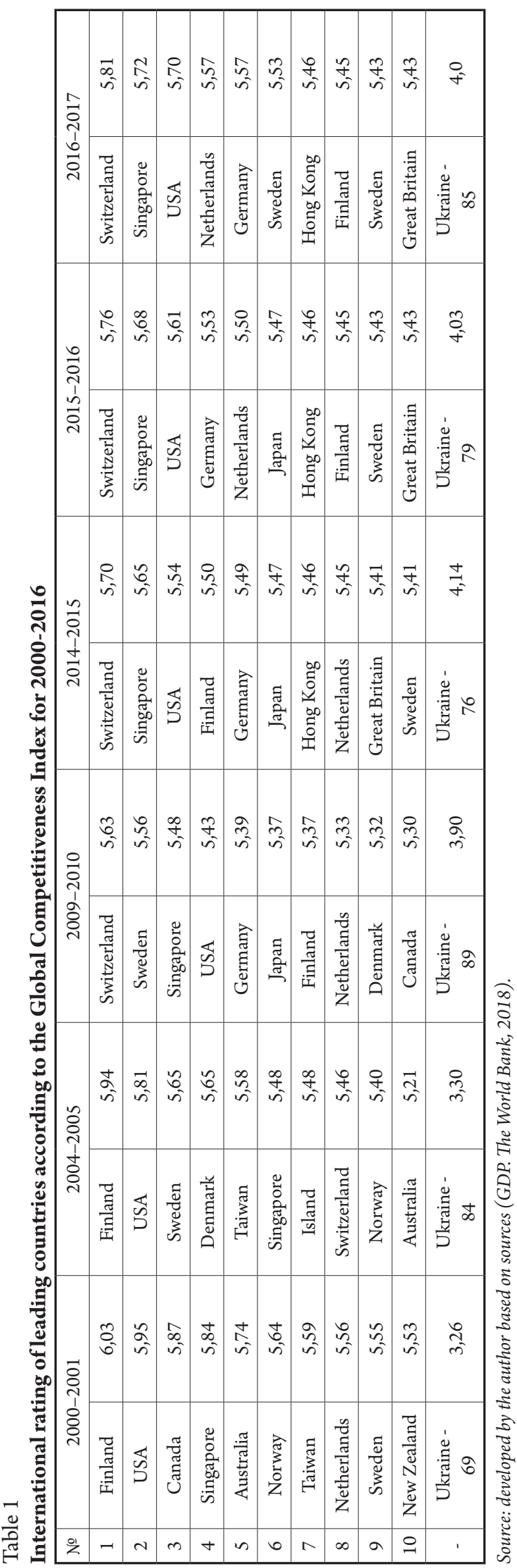

its financial sector, is a consolidation of informal relations and various manifestations of the shadow economy in the economic system and society. Among international ratings, the situation is best reflected by the Corruption Perceptions Index (GDP. The World Bank, 2018). Studies have been conducted since 2005 by Transparency International on the basis of independent surveys of financial experts and human rights defenders and the study of public opinion.

According to the results of 2014, Ukraine ranked 144th among 182 countries, which is comparable with a number of low-income African economies (Cameroon, Congo, Central African Republic, Syria, Bangladesh). As can be seen from the data presented in Table 1, during the analysed period, such countries as Finland, the USA, Singapore, Sweden, and the Netherlands occupy the leading positions in the international rating system according to the Global Competitiveness Index. Assessing the main sub-indices of this Index, it can be argued that these countries position themselves as the main exporters of high-tech equipment and innovative products (Timoshenko, 2016; GDP. The World Bank, 2018). This reaffirms the direct dependence of the level of competitiveness on the country's ability to innovate, on the quality of research institutes, on the share of companies' spending on research and development in their overall structure, on the number of scientists and researchers in the country (the main component subindices "Innovations and Factors of Improvement").

Regarding the rating position of Ukraine, during 2000-2017, under the Global Competitiveness Index, it demonstrated wavering dynamics with a significant lag behind highly developed countries with significant competitive advantages. So, according to the World Economic Forum in 2017, Ukraine ranked 85th among the 138 countries that took part in the rating, losing 6 positions in comparison with 2015 and 16 positions in comparison with 2001.

The main reasons that hamper Ukraine's economic growth and significantly affect the regression by the Global Competitiveness Index are as follows:

1. Waste of state funds, abuse of authority, its corruption, and absence of regulatory mechanisms for creating a security environment (as for example, by the "Institutions" component, Ukraine occupied the 130th place in 2015 and 129th in 2017). According to the given sub-indicator, in the rating of the Global Competitiveness Index, the Ukrainian economy, with full responsibility, can be characterized as kleptocratic, when corruption and abuse are the basis of society's life.

2. By the "Macroeconomic Environment" component, in 2017 Ukraine occupied the 128th place, which is 23 positions lower than in 2015. Of great concern is the decline in rating positions by the indicators "Inflation" and "Government Debt"; 
positive growth was noted in the rating according to the indicators such as "Government Budget Balance" and "Gross National Savings". The reduction of the country's credit rating by almost 2 times (from 66th place in the rating in 2015 to 113th in 2017) is caused by an increase in public debt - according to the Ministry of Finance, the state and state-guaranteed debt of Ukraine in 2015 amounted to 65.5 billion USD, and as of December 31, 2016, it amounted to 1929.76 billion UAH or 70.97 billion USD (Statystyka, 2018). The average annual growth rate of inflation is fixed in the following sizes: in $2014-112.1 \%$; in 2015 $148.7 \%$; in 2016 - 113.9\% (Summary table of inflation indexes, 2018).

3. Ukraine occupies the last positions in the ranking by the index "Goods Market Efficiency" (for example, in 2014 - 112th among 142 studied countries, in 2015 - 106th among 140 countries, in 2016 108 among 139 countries). Despite the improvement of Ukraine's rating positions by this sub-indicator, the competitive environment in Ukraine does not create incentives for entrepreneurial activity; there are no mechanisms for stimulating the development of small and medium-sized enterprises (The position of Ukraine in the world ranking according to the Global Competitiveness Index 2016-2017).

4. The deteriorating position in the development of the financial market (for 2014-2017, Ukraine lost 23 rating positions and ranked 130th) due to inefficient monetary system, in particular, instability of the banking system (according to the NBU, there are more than 80 banks at the stage of liquidation, and payments from the Deposit Guarantee Fund reached $9 \%$ of GDP); fairly low availability of financial services and lack of venture capital.

At the same time, in 2017 compared with 2014, Ukraine significantly improved its positions by the following indices: "Higher Education and Training" by 7 positions, in particular, there were positive changes according to the following sub-indices: "Quality of the Education System", "Quality of Math and Science Education", "Internet Access in Schools"; as for "Labour Market Efficiency", positive dynamics is marked by the following components: "Flexibility of Wage Determination", "Effect of Taxation on Incentives to Work", "Country Capacity to Retain Talent”, "Country Capacity to Attract Talent"; "Innovation”.

\section{Conclusions}

Thus, state management of the development of accelerated integration into world markets and a high level of foreign economic openness are not a guarantee of accelerated economic development, an increase of the international competitiveness of the country. The prerequisites for sustainable longterm economic growth and social progress are issues of domestic economic policy and, in particular, of an institutional nature, which can stimulate selfsustaining development factors, are oriented towards the use of modern innovative technologies and highly skilled human potential.

At the same time, the current state of financial and legal relations allows, in our opinion, noting a few significant problems in the financial services market of Ukraine, namely: 1) insufficient size of own and regulatory capital of banks over the deterioration of the quality of loans and other assets and the creation of additional reserves for active operations; 2 ) a mass exit of large European players in the financial services market from Ukraine; 3 ) decrease in the volume of trades on domestic exchanges; 4) low level of assets of the pension system; 5) insufficient level or complete absence of guarantees of rights to protect the interests of consumers of financial services (including borrowers) and creditors; 6) low-level standards of banking solvency and liquidity management; 7) lack of proper stock market infrastructure; 8) ineffective tax legislation regarding the taxation of investment income and financial services market participants; 9) the abuse of individual financial institutions in terms of loan agreements; 10) low financial literacy of the population; 11) low efficiency of supervision of banks and other financial institutions, which does not allow preventing the development of risks; 12) limited powers and independence of regulators to take measures of influence on participants in the financial sector.

The liberalization of capital movements in Ukraine has no alternative since Article 145 of the Association Agreement between Ukraine and the EU, ratified by the Law of Ukraine as of 16.09.2014 No. 1678-VII provides for harmonization of the legislation of Ukraine with regard to ensuring the free movement of capital in accordance with European standards.

In order to increase the level of competitiveness of the national economy, it is necessary to implement a complex of the following interconnected and consistent organizational and legal measures. In particular: 1) in order to improve rating positions and competitive advantages of Ukraine in global markets, it is necessary to develop additive legal framework and state support program for exportoriented enterprises for the promotion of export of finished products with high added value; 2 ) determine the course of the policy of expansion on the basis of expanding both geographical and commodity structure of exports; 3 ) at the legislative level, support the course of development of the national economy on the basis of self-sufficiency and the policy of "protectionism", which will create an opportunity to reduce the level of import of the country, increase the national economy and in general, will positively affect the economic competitiveness of Ukraine. 


\section{References:}

About the National Anti-Corruption Bureau of Ukraine. Retrieved from: http://zakon0.rada.gov.ua/laws/ show/1698-18

Bondarenko, O. S. (2018). Organizational-institutional regulation of the financial market in Ukraine. Economy and the state. № 7. Retrieved from: http://www.economy.in.ua/pdf/7_2018/5.pdf

Cabinet of Ministers of Ukraine (2018). "On Approval of the Plan of Priority Actions of the Government for 2018". Retrieved from: https://www.kmu.gov.ua/ua/npas/pro-zatverdzhennya-planu-prioritetnih-dij-uryadu-na-2018-rik (Accessed 11 June 2018)

Danylyshyn, B. (2016). Cooperation with the IMF: problems and prospects. Retrieved from: https://zn.ua/ macrolevel/sotrudnichestvo-s-mvf-problemy-i-perspektivy-_html (Accessed 11 June 2018)

Deriv, Alert (2015). News and information about derivative regulatives. Articles by Rebecca Healey and Will Rhode and Miranda Mizen. - Retrieved from: http://www.derivalert.org/blog/?Tag=European\%20Securities\%20 and\%20Markets\%20Authority

Directive 2004/39/EC of the European Parliament and of the Council of 21 April 2004 on markets in financial instruments amending Council Directives 85/611/EEC and 93/6/EEC. Retrieved from: http://eur-lex.europa.eu/ LexUriServ/LexUriServ.do?uri=CELEX:32004L0039:en:NOT

Dinamika denezhnykh agregatov Ukrainy (2018). [Dynamics of monetary aggregates of Ukraine (2018)]. Retrieved from: https://finstat.info/dinamika-denezhnyih-agregatov-ukrainyi

Eteris, Y. U. (2018). Direktiva MIFID: ot obshchego k chastnomu [Eteris Y. MIFID Directive: from general to specific]. Retrieved from: www.baltic-cource.com

European Parliament resolution of 9 October 2008 with recommendations to the Commission on Lamfalussy followup: future structure of supervision (2008/2148(INI). Official Journal of the European Union C 9 E/48 15.1.2010. Retrieved from: http://eur-lex.europa.eu/LexUriServ/LexUriServ.do?uri=OJ:C:2010:009E:FULL:EN:PDF GDP. The World Bank (2018). Retrieved from: http://data.worldbank.org/indicator/NY.GDP.MKTP.CD

Melykh, O. (2013). Financial security of the state: essence, evaluation criteria and preventive measures of strengthening. Ekonomichnyy analiz, 12(2), 266-272.

Oslund, A. (2009). Krizis: Prichiny i posledstviya. Nezavisimaya informatsiya i analitika iz USA [Crisis: Causes and consequences. Independent Information and Analytics from the USA]. Washington Profile. Retrieved from: http/www.washprofile.org/ru/node/8204

President of Ukraine (2015). About the Strategy of Sustainable Development "Ukraine-2020". Retrieved from: http://zakon4.rada.gov.ua/laws/show/5/2015 (Accessed 11 June 2018)

Regulation (EU) (2010) No 1095/2010 of the European Parliament and of the Council of 24 November 2010 establishing a European Supervisory Authority (European Securities and Markets Authority), amending Decision No 716/2009/EC and repealing Commission Decision 2009/77/EC. Official Journal of the European Union 15.12.2010 L 331/84. Retrieved from: http://eur-lex.europa.eu/LexUriServ/LexUriServ. do?uri=OJ:L:2010:331:0084:0119:EN:PDF - Title from screen.

Rekunenko, I. I. (2013). Infrastruktura finansovoho rynku Ukrainy: suchasnyj stan ta perspektyvy rozvytku [Infrastructure of the financial market of Ukraine: the current state and prospects of development], DVNZ UABS NBU, Sumy, Ukraine.

Skrypnyk, N. E., Khyryuddinov, E. O. (2016). Konkurentospromozhnist natsionalnoyi ekonomiky: sutnist i pidkhody do tlumachennya [Competitiveness of the national economy: the essence and approaches to the interpretation]. Naukovyy visnyk Khersonskoho derzhavnoho universytetu, issue 16, part 4, pp. 34-38.

Statystyka (2018). Statystyka zovnishnoho sektoru. Mizhnarodni rezervy. Stan mizhnarodnykh rezerviv ta likvidnist v inozemniy valyuti [Statistics External sector statistics. International reserves. The state of international reserves and foreign currency liquidity]. Retrieved from: https://bank.gov.ua/control/uk/publish/category?cat id $=769306636 / 5000$

The World Bank Group (2018). Retrieved from: https://data.worldbank.org/indicator

The new European (2017). The new European Securities and Markets Authority: helping enhance the resilience of financial markets By Michel Barnier, European Commission For Internal Market \& Services. Retrieved from: http://www.egovmonitor.com/node/42777

Timoshenko, O. V. (2016). Ekonomichna bezpeka natsionalnoyi ekonomiky v umovakh hlobalizatsiyi: monohrafiya [Economic security of the national economy in the conditions of globalization: monograph]. Kyiv: TOV «Nash Format». Treaty establishing the European Community (1957). [Dohovir pro zasnuvannya Yevropeyskoho Spivtovarystva. Ofitsiynyy zhurnal 1957-03-25]. Official Journal, 1957-03-25: European Integration Guide. Retrieved from: http://eu-directory.ru/index.php?act=show\&doc_id=1\&id=74

Treaty on European Union (Maastricht, February 7, 1992). [Dogovor o Yevropeyskom Soyuze (Maastrikht, 7 fevralya 1992)]. Retrieved from: http://zakon2.rada.gov.ua/laws/show/994_029

Verkhovna Rada (2011). About access to public information. Retrieved from: http://zakon3.rada.gov.ua/laws/ show/2939-17 (Accessed 11 June 2018)

Zvedeni statystychni indeksy ynflyatsiyi (2018). [Summary table of inflation indexes]. Retrieved from: http://search.ligazakon.ua/1_doc2.nsf/link1/SH000042 